Volume 4 Issue 2, September 2019: . Copyright @ LamLaj.

Faculty of Law, Lambung Mangkurat University, Banjarmasin,

South Kalimantan, Indonesia. ISSN: 2502-3136 | e-ISSN: 2502-3128.

Open Access at: http: //lamlaj.ulm.ac.id/web/

\title{
RIGHT OF ACCESS TO AREA OF DEPRECIATED LAND REGULATION WITH THE LAW PERSPECTIVE OF LAND REGISTRY IN INDONESIA
}

\author{
Rizky Juliani Wulansari', Yulia Qamariyanti² ${ }^{1}$ Erlina $^{3}$ \\ Master of Notary, Faculty of Law, University of Lambung Mangkurat Jl.Brigjen H. \\ Hassan Basry Banjarmasin 70124 Telp/Fax: +62-4321658 Email: rizkyjulianiwu- \\ lan@gmail.com \\ Faculty of Law, University of Lambung Mangkurat Jl.Brigjen H. Hassan Basry \\ Banjarmasin 70124 Telp/Fax:+62-4321658Email: yulia.qamariyanti@ulm.ac.id \\ Faculty of Law, University of Lambung Mangkurat Jl.Brigjen H. Hassan Basry \\ Banjarmasin 70124 Telp/Fax: +62-4321658Email: erlina@ulm.ac.id
}

Submitted : 05/09/2019 Reviewed 25/09/2019 Accepted:30/09/2019

\begin{abstract}
A Holder of Right has rights and obligation in using his/her land. One of the obligations of a Holder of Right is providing access right to an area of land depreciated which borders with his/her land. The obligation is one manifestation of social function basis. In the social reality, a legal issue pertaining to access to the area of land depreciated bordering with the land ownership. The emerging law issue is the cancelation of Certificate of Right to Own with the issuance basis by taking for granted access right of area of land depreciated and violation of access to area of depreciated land deemed to be an act contradicting the law. The present study is a normative law research. The law research conducted began with inventorization of laws and regulations, judicial decree, governance or other references concerning right of access to an area of depreciated land to be further applied in the relevant cases. There are some legal vacuums (rechtsvacuum) concerning the obligation of Certificate of Right to Own to provide right of access to the area of land depreciated in accordance with the law perspective of land registry in Indonesia. The governance of right of access to area of land depreciated in the laws and regulations in Indonesia is merely stated in Article 13, 31 and 50 of The Government regulation Number 40 of 1996 concerning Right To Cultivate, Building Rights on Land and Right Over Land. The legal solution that can be applied in the relevant issues concerning the obligation of Certificate of Right to Own Holder to provide right of access to an area of depreciated land in Indonesia in by making a separate governance stated in the Laws of Right to Own. In some cases of area of land depreciated cases which have been decided by court, Judge has different consideration and multi-interpretations on the dispute settlement.
\end{abstract}


Keywords: Right to Own; Right of Access to Area of Depreciated Land; Legal Vacuum

\section{INTRODUCTION}

Land is one of the most important elements in national development. In accordance with Article 4 paragraph (2) of Law No. 5 of 1960 concerning Basic Regulations on Agrarian Principles (hereinafter abbreviated and reffered as UUPA), stipulates that holders of land rights are given the authority to use the land if only needed for direct interests related to the use of the land within the limitation according to the UUPA and other higher legal regulations. The social function of any land rights must also always be a guideline for holders of land rights. ${ }^{1}$

One of the obligations of holders of land rights as an embodiment of the social function of land rights is to provide access rights to a depreciated depreciated land which is bordered by their own land. The regulation of depreciated land access rights in Indonesian laws and regulations is only contained in Articles 13, 31 and 50 of PP 40 of 1996 which essentially regulates the obligation for holders of Right to Use, and Right to Build to provide solutions or waterways or other facilities for yard or depreciated land.

Before the UUPA becoming into force, the right to access depreciated land was regulated in the provisions of Article 674 through Article 710 of the Sixth Civil Code Chapter 6 on Servituut (Dedication of Yard). The area of depreciated land in Book II of the Civil Code was declared invalid after the birth of the UUPA. There is no regulation regarding the obligation to provide access to depreci-

1 Arie Sukanti Hutagalung. 2005. Tebaran Pemikiran Seputar Masalah Hukum Tanah. Jakarta: Lembaga Pemberdayaan Hukum Indonesia, p. 19. ated land for holders of Right to Own Sertificate both in the UUPA and in PP 40 of 1996, causing legal vacum in the society and also often legal issues related to access to depreciated land which is bordered by the land of right to own.

Legal issues that occur are the cancellation of Right to Own Sertificate on the basis of its issuance without regard to the right to access depreciated land and violations of the right to access depreciated land which are classified as acts against the law. On top of that, there is no regulation related to the procedure for accessing depreciated land,the sanctions applied if the rights holders violate the obligation to provide access to depreciated land or the mechanism for resolving problems related to access rights of depreciated land.

Based on the description above, it is necessary to study further about the right of access to depreciated land and to conduct research with the title " Right of Access to Area of Land Depreciated Regulation with The Law Perspective of Land Registry In Indonesia."

\section{Problem Formulation}

Based on the preface above, the problem which can be formulated are:

1. How is the regulation for the owner of Right to Own Sertificate to provide the right to access depreciated land in the perspective of land law in Indonesia?

2. What is the legal solutions which can be applied in problems related to the right to access depreciated land in Indonesia?

\section{METHOD}


The research on " Right of Access to Area of Depreciated Land Regulation with The Law Perspective of Land Registry In Indonesia “ is a normative legal research. Legal research begins with an inventory of laws and regulations, decisions of judges and other references related to the right to access depreciated land to be applied in the case. This research begins by identifying the laws and regulations in the field of land law related to the obligation of the Right to Own Sertificate holder to provide access rights to the depreciated land and then apply that to cases that have been decided by the court. Based on the case, it is known that there is a legal vacuum (leemten in het recht) in terms of regulating the obligation of the Right to Own Sertificate holder to provide access rights to the depreciated land. This research is a prescriptive analysis. This study is intended to provide arguments for the results of research so as to give argumentation on the regulation of the rights of depreciated land that reflect the principles of justice and legal certainty.

In this study, the author uses several approaches, including:

1. statute approach

2. conceptual approach

3. case approach

4. case approach

\section{ANALYSIS AND DISCUSSION}

Right Of Access To Area Of Land Depreciated Regulation With The Law Perspective Of Land Registry In Indonesia

Right of Access to Area of Depreciated Land Regulation with The Law Perspective of Land Registry In Indonesia

The regulation of depreciated land access rights in Indonesian laws and regulations is only contained in Articles 13, 31 and 50 of PP 40 of 1996 which essential- ly regulates the obligation for holders of Right to Use, use rights and Right to Build to provide solutions or waterways or other facilities for yard or depreciated land.

The UUPA has made regulation regarding ownership rights in Article 20 to Article 27, however, is only about very basic matters. Article 56 states that as long as the law regarding ownership rights as referred to in Article 50 paragraph (1) has not yet been formed, the provisions of the local customary law and other regulations concerning land rights which give authority as or similar to referred to in Article 20 will be applied, as long as it does not conflict with the spirit and provisions of this law. Because the Law on Right to Own has not yet been formed, there is a legal vacuum related to the obligation for holders of Right to Own to provide access rights to the depreciated land. In facing the legal vacuum, the author tries to make legal finding.

The legal finding method can be applied in this case is analogy. The finding of the law by analogy takes place by seeking general rules from specific regulations and finally digging the principles within them. Here are the statutory regulations which are made to be unwritten and general regulatons applied to some special occurence, while the statutory regulations do not include the special events, however, those certain special events are just similar to the events which are regulated by the statutoy regulations. ${ }^{2}$

Right to Use, Right to Build and Right to Own are types of land rights. Based on this smililarity, so the holders of the Right

2 Sudikno Mertokusumo. 2003. Mengenal Hukum Suatu Pengantar. Yogyakarta: Liberty, p. 177. 
to Own have the obligation to provide solutions or waterways or other facilities or conveniences for the yard or depreciated land area that are locked up as required by the holders of Right to Use, and Right to Build. Beside the analogy, the method of legal finding that can also be applied in dealing with this problem is by using legal narrowing. In narrowing the law, new exceptions or deviations from general regulations are formed. General regulations are applied here for specific legal events or relation with explanations or constructions by giving characteristic. ${ }^{3}$

As explained above, each land right has a social function. This social function is a general rule of law. Based on the existence of the social function of land rights, holders of Right to Own must obey the obligation to provide the right to access depreciated land area. This is due to the authority of the holder of the right to own or use his land is not absolute, but also limited to the interests of others and public interests

\section{Right of Access to Area of Depreciated} Land Regulation in Several Countries

Studying land law in other countries as an alternative to finding solutions or solving problems that are being faced is not a wrong thing to do, as long as it is limited to comparative studies only. We will gain a lot of knowledge and views on how developed countries have governed their land law with wide comparative materials,

The following will describe 3 different laws regarding the access rights of depreciated land area.These are Laws in the Netherlands which are regulated in Nieuw Burgerlijk Wetboek, Laws in Singapore

3 Ibid., p. 179-180. which are regulated in the Land Titles Act 1993 and Laws in Louisiana, United States which are regulated in the Louisiana Civil Code. This comparison of Laws are used as a comparative study to increase knowledge and understanding.

Right of Access to Area of Depreciated Land Regulation in Netherland

Civil law in the Netherlands is regulated in Nieuw Burgerlijk Wetboek which has been ratified since 1992. Nieuw Burgerlijk Wetboek is a substitute for Burgerlijk Wetboek which is still applied in Indonesia today. The right of access to a depreciated land in Nieuw Burgerlijk Wetboek is called erfdienstbaarheden. The definition of erfdienstbaarheden in Article 70 Nieuw Burgerlijk Wetboek is stated as follows: Een erfdienstbaarheid is een last, waarmede een onroerende zaak-het dienende erf - ten behoeve van een andere onroerende zaak - het heers erf-iszwa. Free translation: Erfdienstbaarheden is a charge put on a plot of land belonging to the recipient of the charge, for the benefit of the property of another person who gives the charge. Erfdienstbaarheden is regulated in Sixth Part (erfdienstbaar-heden) Book Five (Real Property Rights) Nieuw Burgerlijk Wetboek. Regulations in Nieuw Burgerlijk Wetboek consist of 15 articles.

Right of Access to Area of Depreciated Land Regulation in Singapore

The Land Law in Singapore is regulated in the Land Titles Act which was ratified in 1993. The regulation of the right of depreciated land access is regulated in Section 10 of the 1993 Land Titles Act. The term for the right of de- 
preciated land area in the Land Titles Act 1993 uses the term easement. The definition of easement in Article 29.4.7 of the Land Titles Act 1993 is stated as follows: An easement is an interest in land that gives a landowner a right or rights over the land belonging to another person. A common example is an easement giving a right of way. Free translation: The easement regulation in the 1993 Land Titles Act consists of 15 (fifteen) articles.

Right of Access to Area of Depreciated Land Regulation in Louisiana, United States

Louisiana (French: Louisiane) is a state in the United States. Land law in Louisiana is regulated in the Louisiana Civil Code. Servitude in the Louisiana Civil Code consists of 2 types of personal servitude and predial servitude, land, for example. Understanding personal servitude as Article 534 Louisiana Civil Code as follows: A personal servitude is a charge on a thing for the benefit of a person. There are three sorts of personal servitudes: usufruct, habitation, and rights of use. Furthermore, the definition of predial servitude as Article 646 of Louisiana Civil Code states as follows: A predial servitude is a charge on a servient estate for the benefit of a dominant estate. In this sub-section, the author only focuses on predial servitude and will not discuss further related to personal servitude. Predial servitude is regulated in Title IV on Predial Servitude which consists of 4 chapters and 129 articles.

There are some similarities or differences in the regulation of land access rights in these three countries. The similarity in regulating the access rights of depreciated land in the Netherlands, Singapore and Louisiana is as follows:

1. There are two parties involved, which are the owner of the land who gives the burden and the land owner who receives the burden;

2. The right of access to a depreciated land area includes the obligation of the landowner receiving the charge to allow something or not do something;

3. There are cost / retribution charged on parties who use access rights;

4. The right of access to a depreciated land continues even though the charge giver of land or charge receiver dialihkan/dibagi.

The fundamental difference in regulating the right of access to depreciated land area in the three countries is related to registration obligations. In Singapore, the right to access depreciated land is a legal interest which generally must be registered. If not registered, there may not be any activity on the land. This is certainly different from that in the Netherlands and Louisiana, the two countries do not require the obligation to register the depreciated land access rights in an official register.

Legal Solutions for the Problem Related to the Right to Access to Depreciated Land Right in Indonesia

Resolution of Issues Related to the Right to Access Depreciated Land Area in Various Decisions of Judges in Indonesia Civil case in Supreme Court Decision Number 509 K/Pdt / 2017 dated July $19^{\text {th }} 2017$

This case occurred between $\mathrm{M}$. 
Saleh Said as Plaintiff and Moch Hisham as Defendant and National Land Agency as Co-Defendant. This case began with the issuance of Right to Own Sertificate Number 0331 and Right to Own Sertificate Number 0332 owned by the Defendant. With its Right to Own Sertificate, the Defendant built a wall around his house to close the access road which is the only way in and out of the Plaintiff's house that has been used for more than 70 years, long before the issuance of Right to Own Sertificate 0031 and Right to Own Sertificate 0332

One of the petitum inthe lawsuit filed by the Plaintiff is to declare the alley / road that is part of the land in Right to Own Sertificate 0031 and Right to Own Sertificate 0332 is as a facility for public use as the access to and from the Plaintiff's house. The decision of the Singaraja District Court which was later confirmed by the Denpasar High Court was to reject the Plaintiffs claim entirely.

The High Court's decision which confirmed the District Court's decision was overturned by the Supreme Court in cassation level. The decision of the Panel of Judges in the case stated that Right to Own Sertificate 0331 and Right to Own Sertificate 0332 were not legally binding and sentenced the Defendant to demolish the building which was on the road / alley used as the way in and out of the Plaintiff's house.

Seeing the differences of opinion, the author agrees with the Supreme Court Judges, it is true that Right to Own are strongest. However, the strongest characteristic does not mean that
Right to Own Sertificate holders can implement their rights absolutely without regard to the interests of others. As stipulated in Article 20 of the UUPA, The right of ownership is hereditary right and be strongest and fullest right one can have on land that may be possessed by citizen and must be based on the principle of social functions of land rights. In addition to this, the reason for the District Judges and High Court Judges to reject the Plaintiff's suit is that the object of the dispute is not a public facility because it is only used for access to the Plaintiff's entry and not for the public. This opinion will lead to the perception that it does not matter causing harm to the interests of others, as long as it does not benefit the public / many people.

Civil case in Supreme Court Decision Number 2607 K / PDT / 2013 dated June $19^{\text {th }} 2014$

This case occurred between Paul J.A. Doko as the Plaintiff against Rohana Kusuma and Daud Adoe as the Defendant. This case began with the Defendant's actions by closing the only entrance to the Plaintiff's house by making a foundation and fencing it with zinc because the Defendant assumed that the land to be included in his own land.

The Panel of Judges at the cassation level considered that the decision of the Kupang High Court which reinforced the decision of the Kupang District Court was inappropriate because it put the social functions over plots of land aside. In the trial, the Plaintiff can prove that the disputed land is the right of ser- 
vituut as referred to in the provisions of Article 674 of the Civil Code.

The author agrees with the Supreme Court Judges that each land has a social function. The Right to Own Sertificate holder has the authority to use or utilize his land. However, this authority does not mean that Right to Own Sertificate holders can exercise their rights absolutely without regard to the interests of others. The social function of land rights is always attached to the use and use of land.

The Panel of Judges of the Supreme Court in its consideration also stated that the disputed land was the right of servituut as regulated in Article 674 of the Civil Code. According to the author, the legal considerations are inappropriate. This is because the provisions of Article 675 of the Civil Code have been declared invalid by the enactment of the UUPA.

Civil case in Supreme Court Decision Number 1427 K/Pdt/2011 dated on April 24 2012

This case occurred between PT. Telekomunikasi Seluler as a plaintiff against Suwarno Soerinta as Defendant and Moh. Yahya as the co-Defendant. The dispute object is the road / access to the land sized $15 \mathrm{~m}$ x $20 \mathrm{~m}$ which was used as a base for GSM Cellular Telecommunication System Base Transceiver Station (hereinafter abbreviated as BTS).

This case began with a lease agreement of $15 \mathrm{~m} \times 20 \mathrm{~m}$ in size for the installation and placement of GSM Cellular Telecommunication BTS, which was made on September 16 ${ }^{\text {th }}, 2002$ un- der Number: PKS.662 / LG.05 / CS.00 / X / 2002 between Plaintiffs and CoDefendant The lease period covers 20 years from September $1^{\text {st }} 2002$ to $\mathrm{Au}-$ gust $31^{\text {st }} 2022$.

During the lease agreement, the Co-Defendant sold his own land including the land leased by the Plaintiff as well as the way to enter the BTS to the Defendant. Since the Defendant had owned his land, the Defendant did not allow the Plaintiff's employees/technicians to take care of the BTS through the road that was allowed by the CoDefendant.

One of the Plaintiffs' petitum suit is that the Defendant's actions that did not give permission for the Plaintiff's technician employees to use the road to the BTS and conduct maintenance on the BTS are illegal. Based on the petition, both the District Court, the High Court and the Supreme Court have the same opinion, namely that the act committed by the Defendant did not give permission to the Plaintiffs' Technician employees to walk down the road to the BTS and to treat BTS was the unlawful act.

The Panel of Judges in their consideration stated that the lease agreement for the installation and placement of BTS between the Plaintiff and the Defendant was made on September $16^{\text {th }}, 2002$ Number: PKS.662 / LG.05 / CS.00 / X / 2002 is lawfull and still valid according to Article 1576 Civil Code.

The provisions of the article above stipulate that the sale and purchase does not remove the lease, unless agreed otherwise. The author agrees that the sale 
and purchase does not eliminating the lease, but this consideration is incomplete. This is because the object of dispute in question is actually not on the land with $15 \mathrm{mx} 20 \mathrm{~m}$ in size that is used as BTS location, but the road / access to the $15 \mathrm{mx} 20 \mathrm{~m}$ land which is used as a BTS location. For this reason, the Panel of Judges should also consider that land has a social function, wherein holders of land rights have the obligation to provide access to depreciated land area due to the existence of their land.

Civil case in Supreme Court Decree Number 1833K / Pdt / 2017 dated September $18^{\text {th }} 2017$

This case occurred amongst Putu Dody Suda and, J.B. Putu Nova Indrayana, I.B. Gde Yudhiana Manuaba, I Made Yoga Suastawa as Plaintiff I, III, V, VI and Nyoman Ardana, I Komang Sudana as Plaintiff II, IV against I Wayan Sudena, Ida Bagus Pangdjaya, Gusti Ngurah Putra Subakti, I Made Pelita as Defendant. The object of the dispute is the right to use or cross the Jalan Sekar Jepun VIII Gang VIII C.

Plaintiffs are residential landowners located on Jalan Sekar Jepun VIII, Gang VIII C, Banjar Kertagraha, Kesiman, Denpasar (new residents). The Plaintiffs intend to build houses on each land of the Plaintiffs. However, the intention is constrained because The Defendant prohibited the Plaintiffs from accessing or using the access of Sekar Jepun VIII Road, especially in Gang VIII C.

One of the Plaintiffs' petitum suit is that the Plaintiffs have the right to also cross and use the access of Sekar Je- pun VIII Road, especially in Gang VIII C. Based on this request, the District Court, the High Court and the Supreme Court have the same opinion, which is rejecting the Plaintiff's suit entirely. The Panel of Judges' consideration is that Sekar Jepun VIII alley VIII C Denpasar Timur Denpasar City is not a road for public facilities or social facilities and is only intended for residents who own land and houses along the Sekar Jepun VIII alley VIII C alley East Denpasar City Denpasar

The Panel of Judges in their consideration stated that a portion of Jalan Sekar Jepun VIII especially Gang VIII $\mathrm{C}$ was personal property of Defendant I according to RIGHT TO OWN SERTIFICATE 2772 and Jalan Sekar Jepun VIII Gang VIII C East Denpasar that way is not a public road but only for residents who own houses and land along the road.

The judge's consideration rule out the principle that all land has a social function. Even though part of Sekar Jepun VIII Gang VIII C Road is privately owned by Defendant I in accordance with RIGHT TO OWN SERTIFICATE 2772 , there is still an obligation to provide access to depreciated land areas. This is in accordance with Article 20 of UUPA jo. Article 6 of UUPA.

If the owner of the depreciated land wants to use the existing access road, the Judge may decide that the owner of the depreciated land is to pay compensation / rent to the Right to Own Sertificate holder whose land is used as an road access. So that justice is created for each party. thus there is no regulation in 
the laws of land in Indonesia. However, according to the Ius Curia Novit principle, judges are considered to know of all laws so that the Court may not refuse to examine and adjudicate cases. This principle is also affirmed in Article 10 of Law Number 48 Year 2009.

Civil case in Supreme Court Decree Number 1744 K / Pdt / 2012 dated May $21^{s t}, 2013$

This case occurred between Herry Rusianto as Plaintiff, Catry Jintar, Afrizal, Andri Zulisman, Erna Dwi and Lizana as Defendants and BPN as CoDefendants. In 2001, the Right to Own Sertificate 1600 owned by the Defendant was published. In the Right to Own Sertificate 1600 map there were no roads bordering the Plaintiff's land. Whereas in the Plaintiff's Right to Own Sertificate 00072 which had been published since 1991 there was a road plan bordering the land owned by the Defendant. Because the Defendant thought having authority over his land, the Defendant took the road blocking action that was often used by the Plaintiff since 1991 to enter and leave his house.

One of the plaintiff's petitum is to order the Defendant to return the position of the road that had been used by the Plaintiff as before. Based on the petition, the District Court, the High Court and the Supreme Court held the same opinion, which is ordering the Defendant to immediately vacate the location of the land and return the position of public roads that had been existing and used by the community to a normal condition.

The Panel of Judges in their con- sideration stated that the construction of the public road had been in existence since 1991 (in accordance with Right to Own Sertificate 00072) and that the Defendant I was only in 2001 in his measurement letter and there was no road plan according to what is stated in Right to Own Sertificate 00072. The judge's consideration is more like the obligation to provide access to roads because, historically there has been a road that was used previously as access to go in and out of the Plaintiff's house rather than the obligation of the Right to Own Sertificate holder to provide access to the depreciated area due to being covered by his land. The decision of the Panel of Judges that needs to be reviewed is ordering the Defendant to change the road plan and adjust the road position in accordance with the Plaintiff's Right to Own Sertificate 00072 and to propose it back to the National Land Agency. The panel of judges did not state that Right to Own Sertificate 1600 had no legal force, instead they ordered changes in physical data on Right to Own Sertificate 1600

The author agrees with the decision because it reflects more justice and expediency for the parties than by stating Right to Own Sertificate does not have legal power as in the Supreme Court Decision Number 509 K / Pdt / 2017 dated July $19^{\text {th }}, 2017$.

This rarely happens, the District Court Judges granted the Plaintiffs' demands, which is ordering Defendant I to stop the construction and / or piling of roads on land until a court decision has permanent legal force. 
The author agrees with the Panel of Judges who granted the provision in disputes related to the right to access depreciated land area because it plays an important role. The longer the issue is examined in court while awaiting an inkracht decision, the greater the loss will be experienced by the owner / user of the landlocked. The period of time required for an inkracht verdict to be calculated from the beginning of the loss suffered by the owner / user of the landlocked land on average reaches 2 to 2.5 years.

The loss incurred economically will be very large if there is no provision decision, for example the owner of a landlocked land cannot carry out activities in his own house, so he must find another place to live. Major loss was also seen in the case of PT. Telkomsel is unable to perform BTS maintenance because its employees are not permitted to enter BTS maintenance that must pass through someone else's land. The ban certainly disrupts the business of PT. Telkomsel, so the loss suffered will be very large because it is used for commercial.

Settlement of disputes related to the obligation of Right to Own Sertificate holders to provide access to the land parcels based on an analysis of the five decisions of judges which are already inkracht, known from the following matters:

1. Not all law enforcers (judges) understand that the principle of land has a social function as regulated in Article 6 of the UUPA. There are still judges who are of the view that property rights are the highest ownership relation, so the conduct of Right to
Own Sertificate holders who build walls on their land is not illegal, even though it is detrimental to others.

2. There are still judges who are guided by the regulation of servituut rights as stipulated in Article 674 of Book II of the Civil Code, even though Book II of the Civil Code concerning the earth, water, and natural resources contained therein has been declared invalid by the enactment of the UUPA.

3. There is a different opinion among the Judges regarding the granting of access to a depreciated plot of land for the benefit of the public or individuals only. On one hand, the Judge said that the right of access to depreciated land area is a public facility that is used for going in and out of public. The other side is the judge said that the right to access depreciated land area is not only intended for public, but to anyone whose interests are urged due to the use of such access.

4. The judge rarely granted the demand of provision relating to the termination of activities that led to the closure of the access road or the granting of permission to use the access road that covered the landlocked. Even though it plays an important role in disputed rights over depreciated land area. The longer the matter is examined in court while awaiting an inkracht ruling, the greater the loss will be experienced by the Plaintiff.

5. The judge stated that the Right to Own Sertificate did not have any 
valid legal force on the basis that the data contained in the Right to Own Sertificate included parts of land used as roads. It would be better if the Panel of Judges considered ordering the Right to Own Sertificate holder to make changes to the certificate's physical data rather than stating the certificate had no legal force. The alternative to make changes to the physical data on the certificate could minimize more the loss that will be experienced by the disputing parties rather than having to repeat the steps from the beginning to only get the certificate because a small portion of the land is used as a road.

Because there are inconsistencies in dispute resolution related to the obligation of Right to Own Sertificate holders to provide access to the derpeciated land area in several decisions of judges who have been incracht, a regulation is needed that can guarantee a justice expediency and legal certainty.

\section{The Future Regulation on The Depreciated Land Access Right in Indonesia}

The obligation of the Right to Own Certificate holder to provide access rights to the depreciated land needs to be regulated in the Law on Property Rights. The author compiles several provisions that need to be regulated in relation to Right to Own Sertificate holders' obligations to provide access rights to depreciated land in the Right of Ownership Act, which basically regulates the following matters:

1. The scope of access rights of depreciated land

2. The General Principles

3. The Emersion rights of depreciated land area

4. The Obligations and Rights of the Parties

5. The use of depreciated land area access rights by other parties

6. Judge's Authority

7. The Elimination of the right to access the depreciated land

8. The Expiration of the right to access the depreciated land area

\section{CONCLUSION}

1. There is a legal vacuum related to the obligation of the holder of the Certificate of Ownership to provide access rights to the depreciated land in the perspective of land law in Indonesia. The regulation of depreciated land access rights in Indonesian laws and regulations is only contained in Articles 13, 31 and 50 of Government Regulation No. 40 of 1996 concerning Right to Cultivate, Right to Build and Right to Use over land which essentially regulates the obligation of the holder of Right to Cultivate, Right to Build and Right to Use to provide access for the way in and out or waterway or other ease for lawns or plots of land that are bound to it.

2. The legal solution that can be applied in the issue related to the obligation of the holder of a Certificate of Ownership to provide access rights to the depreciated land in Indonesia is that the Judge in resolving disputes always prioritizes the social function of land rights as stipulated in Article 6 of Law No. 5 of 1960 concerning Basic Regulations on Agrarian Principles and making separate arrangements contained in the law, namely the Property Rights Law.

\section{Recommendation}

1. For this reason, lawmakers should imme- 
diately compile and ratify the Property Rights Law as mandated by Article 50 paragraph (1) of Law No. 5 of 1960 concerning Basic Regulations on Agrarian Principles, in which it clearly regulates the obligation of holders of a Certificate of Property Rights to grant access rights to the depreciated land area.

2. In order for the Judge to decide on disputes related to the obligations of the Certificate of Ownership to prioritize the social function of land rights. This is intended to prevent differences in interpretation of similar cases.

\section{BIBLIOGRAPHY}

Harsono, Boedi. 2000. Hukum Agraria Indonesia: Himpunan Peraturan-Peraturan Hukum Tanah. Jakarta: Djambatan.

Hutagalung, Arie Sukanti. 2005. Tebaran Pemikiran Seputar Masalah Hukum Tanah. Jakarta: Lembaga Pemberdayaan Hukum Indonesia.

Mertokusumo, Soedikno. 2003. Mengenal Hukum Suatu Pengantar. Yogyakarta: Liberty.

Decision of Court of Singaraja Number 233/ Pdt.G/2015/PN Sgr dated on April 20 ${ }^{\text {th }}$ 2016 jo. Decision of High Court of Denpasar Number 103/PDT/2016/PT.DPS dated on August $24^{\text {th }} 2016$ jo. Decision of Supreme Court Number 509 K/Pdt/2017 dated on July $19^{\text {th }} 2017$.

Decision of Court of Kupang Number: 09/ PDT.G/2012/ PN.KPG dated on July $19^{\text {th }}$ 2012 jo. Decision of High Court of Kupang Number: 114/PDT/2012/PTK dated on January $18^{\text {th }} 2013$ jo. Decision of Supreme Court Number: 2607 K/PDT/2013 June $19^{\text {th }} 2014$.

Decision of Court of Jambi Number:61/
Pdt.G/2009/PN.Jbi dated on March $24^{\text {th }}$ 2010 jo. Decision of High Court of Jambi Number: 45/PDT/2010/ PT.JBI dated on December $22^{\text {th }} 2010$ jo. Decision of Supreme Court Number 1427 K/Pdt/2011 dated on April 24 2012.

Decision of Court of Denpasar Number: 373/ Pdt.G/2015/PN.Dps dated on December $10^{\text {th }} 2015$ jo. Decision of High Court of Denpasar Number: 50/PDT/2016/ PT.DPS dated on June $7^{\text {th }} 2016$ jo. Decision of Supreme Court Number 1833K/ Pdt/2017 dated on September $18^{\text {th }} 2017$.

Decision of Court of Tanjung Pinang Number: 41/Pdt.G/2009/ PN.TPI dated February $16^{\text {th }} 2010$ jo Decision of Supreme Court Number 1744 K/Pdt/2012 dated on May $20^{\text {th }} 2013$.

\section{Regulations}

Republic of Indonesia Constitution Year 1945.

Civil Code (Staatsblaad Number 23 Year 1847 concerning Burgerlijk Wetboek Voor Indonesie).

Law Number 5 Year 1960 Concerning Basic Regulation on Agrarian Principles (Republic of Indonesia State Gazzete Year 1960 Nomor 58, Republic of Indonesia Additional State Gazzete Number 4843). Law Number 48 Year 2009 concerning Judicial Power (Republic of Indonesia State Gazzete Year 2009 Number 157, Republic of Indonesia Additional State Gazzete Number 5076);

Government Regulation No. 40 Tahun 1996 Concerning Right to Cultivate, Right to Build and Right to Use over Land (Republic of Indonesia State Gazzete Year 1996 Number 58, Republic of Indonesia Additional State Gazzete Number 3643). 